\title{
Total wall resection by full-thickness resection device post-hybrid endoscopic submucosal dissection of a laterally spreading tumor in the colon
}

Non-lifting lesions can occur owing to fibrosis caused by multiple biopsies, submucosal tumor involvement, and lesions resulting from incomplete resections, among others. These lesions can be successfully resected using the full-thickness resection device (FTRD) [1-5]. Here we report the case of a patient who, after undergoing endoscopic submucosal dissection, presented with lesion recurrence. In light of this, the decision was taken to perform resection with the FTRD.

A colonoscope with a conical cup was advanced to the hepatic flexure of the colon, where a flat, granular-type, laterally spreading tumor of approximately $4 \times 6 \mathrm{~cm}$, covering $40 \%$ of the perimeter and a complete haustral fold longitudinally, was identified ( $\triangleright$ Fig. 1 a). The margins of the lesion were clearly identified.

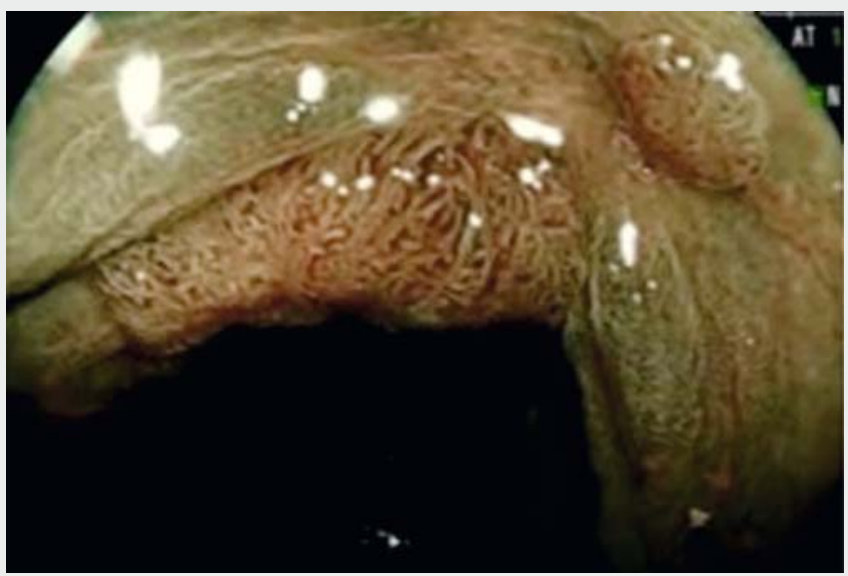

Video 1 A laterally spreading tumor in the colon is treated by hybrid endoscopic mucosal resection; recurrent adenomatous tissue is treated with a full-thickness resection device (FTRD); the final follow-up colonoscopy shows only the scar from the total wall resection with no adenomatous tissue present.
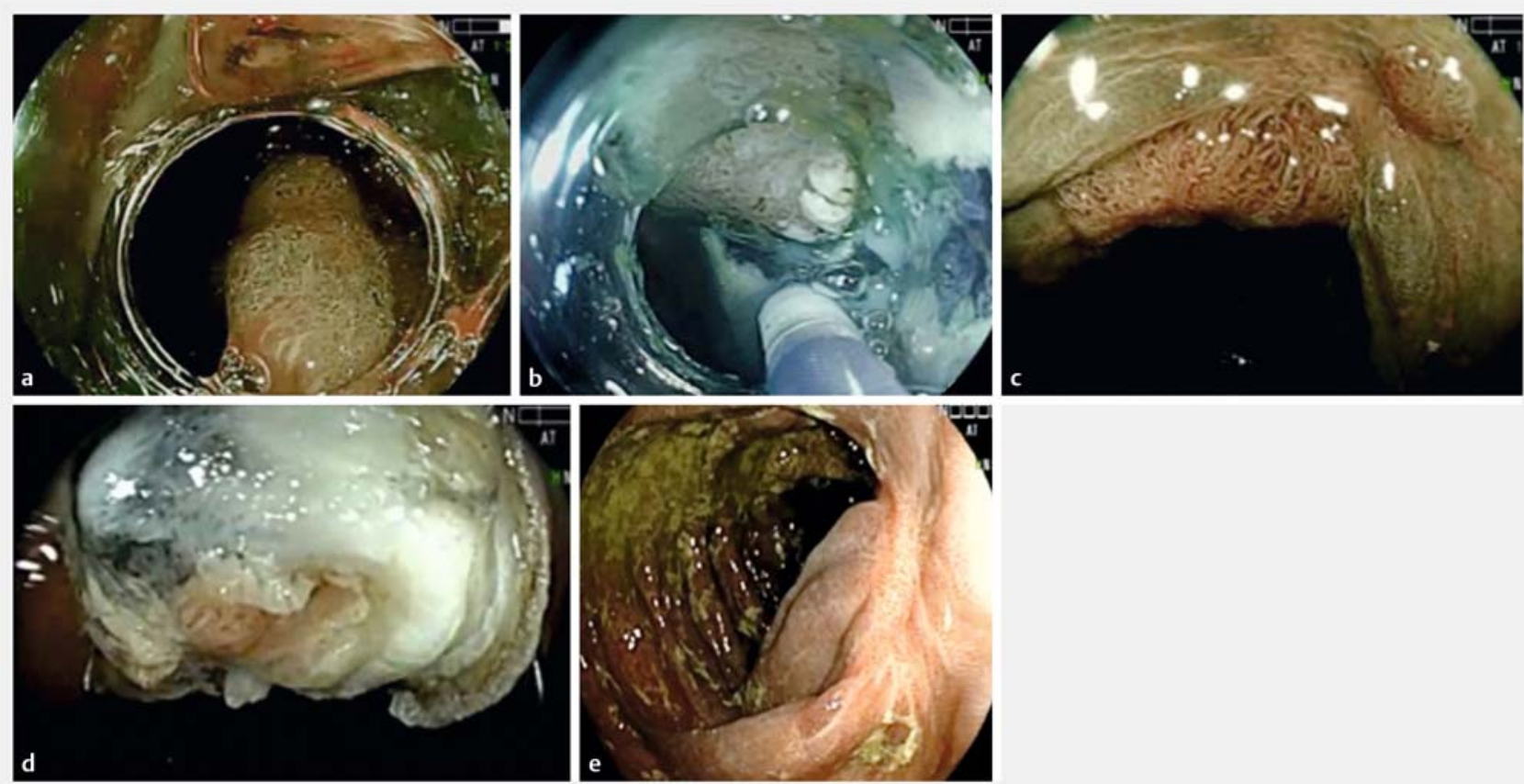

-Fig. 1 Endoscopic views showing: a a flat lesion with agranular lateral extension of about $4 \times 6 \mathrm{~cm}$, occupying $40 \%$ of the total perimeter and an entire haustral fold; $\boldsymbol{b}$ endoscopic submucosal dissection (ESD) being performed; $\mathbf{c}$ scar folds from the previous ESD with residual adenomatous tissue on colonoscopy 6 months later; $\mathbf{d}$ complete wall resection of the segment that contained the residual lesion using the full-thickness resection device (FTRD); e evidence of a flat scar but no residual adenomatous tissue on the final follow-up colonoscopy. 
Submucosal injection was performed to achieve complete elevation of the lesion. Perimeter mucotomy and subsequent endoscopic submucosal dissection (ESD) of the lesion were performed ( $\triangleright$ Fig. 1 b). ESD was then continued from the perimeter toward the center, achieving dissection of almost $90 \%$ of the lesion. Because the distal edge contained a fold, which prevented adequate submucosal dissection, the decision was taken to complete excision of the lesion via snare polypectomy, subsequently fulgurating the mucous borders of the ulcer site ( $\vee$ Video 1 ).

A colonoscopy repeated at 6 months revealed recurrence of the adenomatous tissue ( $>$ Fig. 1 c). Therefore, on this occasion, resection with the FTRD was decided upon. Traction was applied to the tumor fold with a foreign body clamp, and this was followed by aspiration of the tumor into the FTRD ( $\mathbf{F i g . 1 d}$ ). The FTRD was then released, subsequently resulting in total wall resection of the segment containing the lesion. On a further colonoscopy, 6 months after the first follow-up colonoscopy, only the scar from the previous complete wall resection was visible ( $\triangleright$ Fig. 1 e).

In conclusion, use of the FTRD represents a good alternative for recurrent colonic lesions after previous endoscopic resection.

Endoscopy_UCTN_Code_TTT_1AQ_2AD
Competing interests

The authors declare that they have no conflict of interest.

\section{The authors}

Sergio Rubel Cohen ${ }^{1}$, Fernando Bartolome Fluxa Garcia², Pablo Fabre1, Damian Orellano Perassi ${ }^{1}$, Daniel Castellon Garcia ${ }^{1}$

1 Department of Endoscopy, Hospital Barros Luco Trudeau, Santiago de Chile, Santiago, Chile

2 Department of Endoscopy, Clinica Las Condes, Las Condes, Metropolitan Region, Chile

\section{Corresponding author}

\section{Sergio Rubel Cohen, MD}

Hospital Barros Luco Trudeau, Endoscopy, Gran Avenida Jose Miguel Carrera 3204, Santiago de Chile, Santiago, Region Metopolitana 13130, Chile sergiorubelc@gmail.com

\section{References}

[1] Ludwig F, Hildenbrand R. Endoscopic resection techniques for colorectal neoplasia: current developments. World J Gastroenterol 2019; 25: 300-307

[2] Schurr MO, Baur FE, Krautwald M et al. Endoscopic full-thickness resection and clip defect closure in the colon with the new FTRD system: experimental study. Surg Endosc 2015; 29: 2434-2441

[3] Fähndrich M, Sandmann M. Endoscopic fullthickness resection for gastrointestinal le- sions using the over-the-scope clip system: a case series. Endoscopy 2015; 47: 76-79

[4] Richter-Schrag H], Walker C, Thimme R et al. [Full thickness resection device (FTRD). Experience and outcome for benign neoplasms of the rectum and colon]. Chirurg 2016; 87 : 316-325

[5] Backes Y, Kappelle WFW, Berk L et al. Colorectal endoscopic full-thickness resection using a novel, flatbase over-the-scope clip: a prospective study. Endoscopy 2017; 49: 1092-1097

Bibliography

Endoscopy 2021; 53: E374-E375

DOI 10.1055/a-1298-4027

ISSN 0013-726X

published online 3.12 .2020

(c) 2020. Thieme. All rights reserved.

Georg Thieme Verlag KG, Rüdigerstraße 14, 70469 Stuttgart, Germany

ENDOSCOPY E-VIDEOS

https:/|eref.thieme.de/e-videos

口回 Endoscopy E-Videos is a free ry access online section, reporting 自舴: on interesting cases and new techniques in gastroenterological endoscopy. All papers include a high quality video and all contributions are freely accessible online.

This section has its own submission website at https://mc.manuscriptcentral.com/e-videos 